\title{
Complete recovery of right forebrain signs from presumptive cerebrovascular origin in an eight-year-old sport horse
}

\author{
Volledig herstel van een vermoedelijke cerebrovasculaire aandoening van de rechter \\ voorhersenen bij een achtjarig sportpaard
}

\author{
${ }^{1}$ Z. Neuckermans, ${ }^{2}$ J. Rijckaert, ${ }^{3}$ K. Kromhout, ${ }^{4}$ M. Hoegaerts, ${ }^{1}$ G. van Loon
}

${ }^{1}$ Department of Large Animal Internal Medicine, Faculty of Veterinary Medicine, Ghent University, Salisburylaan 133, B-9820 Merelbeke, Belgium

${ }^{2}$ Dierenartspraktijk Caballance, Slenderstraat 14, B-2500 Lier, Belgium

${ }^{3}$ Department of Veterinary Medical Imaging and Small Animal Orthopedics, Faculty of Veterinary Medicine, Ghent University, Salisburylaan 133, B-9820 Merelbeke, Belgium

${ }^{4}$ Equisound, Equine Clinic and MRI Center, Kleine Dries 4, B-9910 Ursel, Belgium

\section{Zoe.Neuckermans@ugent.be}

\section{$\Lambda_{\text {bStract }}$}

In this case report, an eight-year-old Warmblood gelding is described with a presumptive vascular event resulting in severe head turn and circling to the right. The horse recovered completely from the clinical signs. Pathologies that cause asymmetrical forebrain signs in horses could be excluded. Magnetic resonance imaging revealed a flow difference in the venous sinuses that was presumably caused by cerebral venous sinus thrombosis. The horse was treated with prednisolone, antibiotics, vitamin E and B1 and acetylsalicylic acid. He was represented one month after the initial clinical signs and was clinically and neurologically normal. The horse subsequently returned to his previous level of jumping.

\section{SAMENVATTING}

In deze casuïstiek wordt een achtjarige warmbloedruin beschreven met een vermoedelijke vasculaire aandoening die resulteerde in ernstige "head turn" en compulsief cirkelen naar rechts. Het paard herstelde en de klinische symptomen verdwenen volledig. Aandoeningen die asymmetrische symptomen van de voorhersenen bij paarden veroorzaken, werden uitgesloten. Onderzoek door middel van magnetische resonantie toonde een verschil in bloedvloei in de veneuze sinussen, wat vermoedelijk veroorzaakt werd door een cerebrale veneuze sinustrombose. Het paard werd behandeld met prednisolone, antibiotica, vitamine E en B1 en acetylsalicylzuur. Een maand na de eerste klinische symptomen was het paard klinisch en neurologisch normaal. Het paard keerde vervolgens terug naar zijn vorige niveau in de jumping.

\section{INTRODUCTION}

Asymmetrical forebrain pathology can be associated with head and neck turn with or without head tilt, circling, changes in behavior or consciousness, seizures, visual problems and facial sensation abnormalities. Acute onset of these forebrain signs is regularly seen in small animal neurology (Bagley et al., 1999; Erlen et al., 2018). The most common causes in dogs are epilepsy, auto-immune inflammation, cerebrovascular disease and neoplasia. Compared to small animals, the literature regarding forebrain pathology in horses is limited. Differential diagnosis of forebrain pathology also includes trauma, inflammatory (infectious or noninfectious), metabolic or toxic disease (Divers, 2006; Hillock et al., 2006). Cerebrovascular disease is defined as any abnormality of the brain resulting from a pathological process compromising 
its blood supply (Kalimo et al., 2002). Pathological processes that may result in cerebrovascular disease include vascular occlusion by a thrombus or embolus (ischemic stroke), lesion or altered permeability of the blood vessel wall (hemorrhagic stroke) and increased viscosity or other changes in the quality of the blood (Adams and Victor, 1997). Cerebrovascular accident (CVA) or stroke, defined as a sudden onset of nonconvulsive and nonprogressive focal brain signs secondary to cerebrovascular disease, is the most common clinical presentation of cerebrovascular disease in human patients (Sacco, 1994). CVA is characterized clinically by a peracute or acute onset of focal, asymmetrical and nonprogressive brain dysfunction (Thomas, 1996). In humans, strokes are common and about $80 \%$ are ischemic (Béjot et al., 2016). In small animals, strokes are reported to be uncommon but when present, the majority of them appear to be ischemic. The overall prevalence is unknown (Wessman et al., 2009; Gonçalves et al., 2011). There is no reported prevalence regarding horses. In small animals, the diagnosis is usually based on anamnesis, clinical examination, advanced medical imaging and cerebrospinal fluid analysis to rule out inflammatory disease (Garosi, 2010; Yenigün et al., 2015). Imaging studies of the brain (computed tomography, conventional and functional magnetic resonance imaging (MRI)) are necessary to reinforce the suspicion or confirm the stroke, define the vascular territory involved, determine the extent of the lesion and distinguish between ischemic and hemorrhagic stroke. They are also necessary to rule out other causes, such as neoplasia, trauma and encephalitis. Once a stroke is confirmed, diagnostic tests focus on identifying an underlying cause (Garosi, 2010). In humans, the cause of the stroke remains undetermined in up to $40 \%$ of the cases; these cases are called cryptogenic (Sacco, 1994). The prognosis depends on the neuroanatomical location, initial severity of the neurological deficit, the initial response to supportive care and the severity of any underlying cause (Garosi and McConnell, 2005; Garosi, 2010). Most dogs with ischemic stroke tend to recover within several weeks with only supportive care (Garosi and McConnell, 2005; Kang et al., 2007). In this case report, an eight-year-old Warmblood gelding is presented with a presumptive vascular event resulting in severe head turn and circling to the right; the horse recovered completely from the clinical signs.

\section{CASE HISTORY}

An eight-year-old Warmblood sport horse gelding was presented at the Large Animal Internal Medicine Department of Ghent University because of neurological signs since two days. At home, the horse showed a head turn to the right, compulsive circling to the right and the gait was considered slightly imbalanced. The horse had been treated with a single dose of 0.1 $\mathrm{mg} / \mathrm{kg}$ bwt dexamethasone (Rapidexon ${ }^{\circledR} 2 \mathrm{mg} / \mathrm{ml}$, Eurovet Animal Health BV, the Netherlands) intravenously (IV) on the first day of the symptoms by the referring veterinarian. Two days later, the horse was referred to the clinic as the clinical signs did not improve. The horse had no previous medical history, had not been travelling abroad and had not been in contact with travelling horses.

\section{CLINICAL FINDINGS}

\section{Physical examination}

The gelding was bright, alert and responsive. Heart rate ( 44 beats/min), respiratory rate (12 breaths/ min) and temperature $\left(37.8^{\circ} \mathrm{C}\right)$ were normal. Also heart and lung auscultation were normal. The mucous membranes were pink, the capillary refill time was less than two seconds and the pulse quality was good. No petechiae were observed and there were no swollen lymph nodes. The body condition score was $6 / 9$. There were no external signs of trauma. The horse presented a clear head turn to the right.

\section{Neurological examination}

Evaluation of intracranial disease through the mental status and attitude in the quiet stable environment revealed an alert and responsive horse with appropriate response to stimuli. There was an obvious severe head turn, also called lateral 'deviation', to the right with compulsive circling to the same side (Figure 1). There was no head tilt. On examination of the

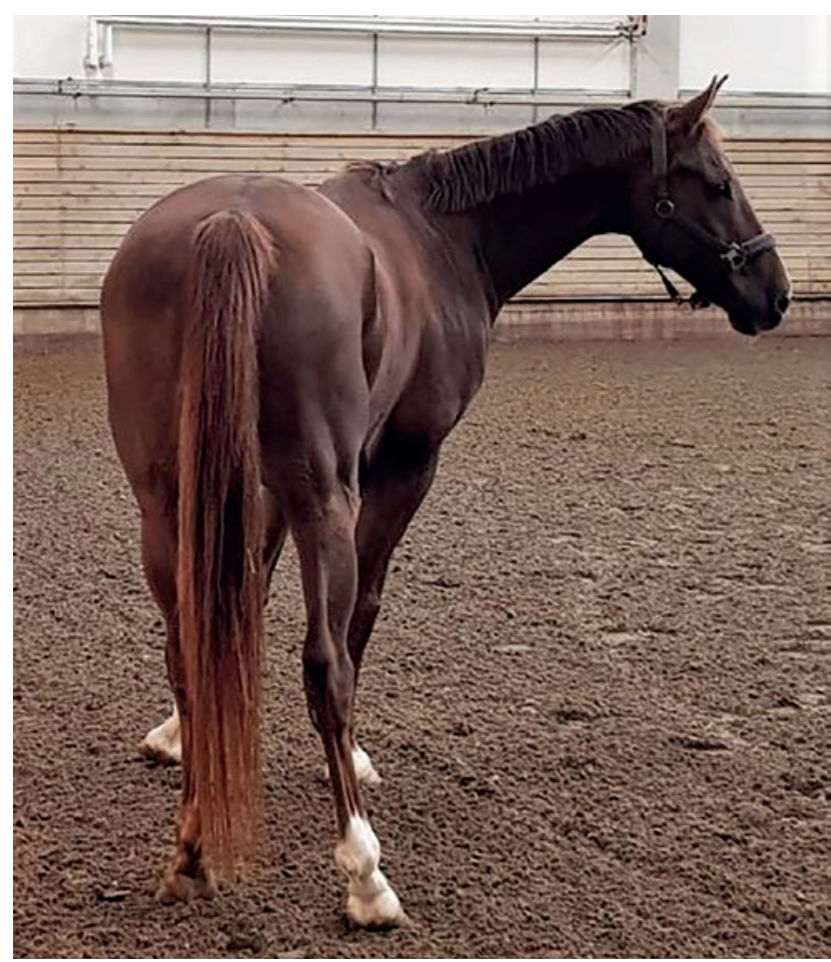

Figure 1. Eight-year-old sport horse with right head turn and continuous compulsive circling to the right. 
cranial nerves to detect any brainstem or peripheral nerve disease, the menace response, palpebral and pupillary light reflexes on the right side appeared to be slightly decreased. No myosis or mydriasis and no ptosis were observed. The face was symmetric. There was no nystagmus present. Tongue tone and swallowing were normal. The evaluation of spinal reflexes and muscle evaluation were also unremarkable. There was a normal panniculus response, tail tone and anal tone. There was no abnormal sweating and no muscle atrophy. No ataxia or paresis were noted at rest and during dynamic evaluation, which made cerebellar, vestibular or spinal involvement unlikely. Blindfolding was not included in the examination. Coordination during lunging exercise at walk, trot and gallop was normal. However, the horse kept leaning on the outside of the circle when lunged on the left hand side and kept coming to the inside of the circle when lunged on the right-hand side. After the neurologic examination, neuroanatomic localization of the lesion was presumed to be of cerebral origin and ancillary tests were performed.

\section{DIAGNOSIS}

\section{Laboratory findings}

Hematology and serum biochemistry were performed on presentation and the results were all within the reference range. Serum western blot did not detect antibodies against Sarcocystis neurona, a causative agent of equine protozoal myeloencephalitis (EPM), and western blot analysis for Borrelia burgdorferi antibodies was negative.

\section{Computed tomography scan and cerebrospinal fluid}

Computed tomography (CT) of the head was performed under general anesthesia on the second day after presentation (fourth day after the onset of clinical signs) using a four-slice helical CT device (Lightspeed Qx/i, General Electric Medical Systems, Milwaukee, WI) with images in soft tissue and bone algorithm with and without IV iodinated contrast agent

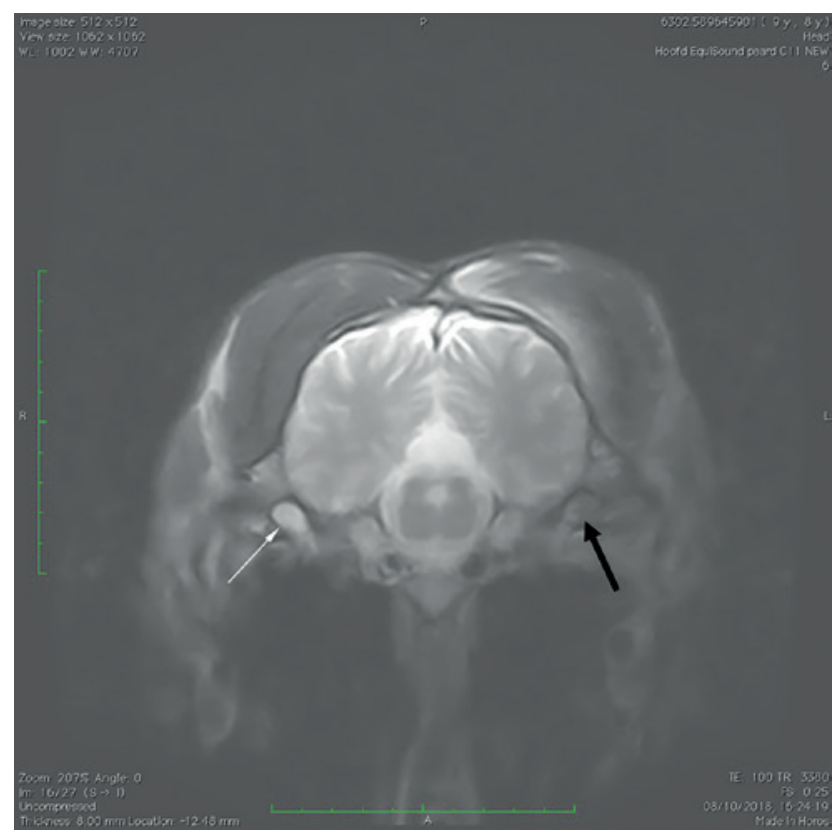

Figure 2. Transverse T2W image of the brain: a hyperintense right petrous venous sinus (white arrow) and isointense left petrous venous sinus (bold black arrow) are present.

(Ultravist $300 \mathrm{mg}$ Iodine $/ \mathrm{mL} ; 400 \mathrm{ml} / 500 \mathrm{~kg}$ bwt). Contrast agent was injected at the speed of $5 \mathrm{ml} / \mathrm{s}$ in both jugular veins using a power injector, and images were acquired 60 seconds after injection. The results of the CT examination were unremarkable both with and without contrast.

Immediately following the $\mathrm{CT}$ examination, cerebrospinal fluid (CSF) was collected from the atlantooccipital space using a 3.5 inch 19-gauge spinal needle (Spinocan ${ }^{\circledR}, \mathrm{B}$. Braun, Germany). The procedure was smooth and a non-contaminated sample was obtained. The CSF was clear and colorless. Total cell count analysis (ProCyte $\mathrm{Dx}^{\mathrm{TM}}$, Idexx Laboratories), performed within thirty minutes of sample collection, revealed no leukocytes. No cells were observed after cytocentrifugation of the sample. Total protein, glucose, aspartate transaminase (AST), lactate and creatine kinase (CK) were within normal range. The sample was sent to an external laboratory and no immunoreactivity was detected for Sarcocystis neurona. The results of the fluid analysis are reported in Table 1.

Table 1. Results of the CSF analysis (Mayhew et al., 1997; Aleman, 2018).

\begin{tabular}{lll}
\hline Parameter & Result & Reference \\
\hline Color & Translucid & Translucid \\
White blood cells count & 0 cell/ $\mu \mathrm{L}$ & $0-6$ cells $/ \mu \mathrm{L}$ \\
Cytology & No cell observed & No cells \\
Total protein & $<5 \mathrm{mg} / \mathrm{dL}$ & $<100 \mathrm{mg} / \mathrm{dL}$ \\
Glucose & $30 \mathrm{mg} / \mathrm{dL}$ & $40-80 \mathrm{mg} / \mathrm{dL}$ \\
AST & $14 \mathrm{IU} / \mathrm{L}$ & $0-50 \mathrm{IU} / \mathrm{L}$ \\
Lactate & $2 \mathrm{mmol} / \mathrm{L}$ & $<2 \mathrm{mmol} / \mathrm{L}$ \\
CK & $<10 \mathrm{IU} / \mathrm{L}$ & $0-8 \mathrm{IU} / \mathrm{L}$ \\
Sarcocystis neurona (Western Blot) & Neg & Neg \\
\hline
\end{tabular}

AST: aspartate transaminase; CK: creatine kinase; Neg: negative 


\section{Magnetic resonance imaging (MRI)}

One week after the start of the clinical signs, magnetic resonance imaging (MRI) of the brain was performed using a low-field 0.25 Tesla MR scanner (VetMR Grande, Esaote, Genova, Italy). The sequences included transverse plane T1- and T2-weighted (T1W, T2W), FAST fluid attenuated inversion recovery (FLAIR) and short tau inversion recovery (STIR) sequences and sagittal plane T2-weighted and 3D hybrid contrast enhancement (HYCE) sequences. MRI changes showed an asymmetry in the signal (T2W, FLAIR and STIR hyperintense right and isointense left compared to the temporal muscles, and $\mathrm{T} 1 \mathrm{~W}$ isointense on both sides) of the ventral petrous venous sinus (Figure 2). Contrast agent was used as for standard brain imaging and no vascular (angiography) protocol was used. Contrast agent was manually injected unilaterally in the jugular vein (Clariscan 0.5 $\mathrm{mmol} / \mathrm{ml} ; 30 \mathrm{ml} / 500 \mathrm{~kg}$ bwt). Images were acquired immediately after injection. Post contrast, a filling defect was present in the left venous sinus. Based on the MRI, there was suspicion of a cerebral venous sinus thrombosis.

\section{TREATMENT}

The horse stayed at the clinic for five days and treatment was initiated with antibiotics (trimethoprim-sulfadiazine; $30 \mathrm{mg} / \mathrm{kg}$ bwt, per os twice a day), prednisolone (1 mg/kg bwt per os once a day) and vitamin $\mathrm{E}$ (7000 IU per os once a day) and B1 (5g per os once a day). During this period, the compulsive turning to the right gradually disappeared. The head turn improved but remained present. After discharge, oral prednisolone $(1 \mathrm{mg} / \mathrm{kg}$ bwt once a day for two weeks followed by $0.5 \mathrm{mg} / \mathrm{kg}$ bwt once a day for one week) and trimethoprim-sulfadiazine were continued for three and two weeks, respectively. The horse was also daily orally supplemented with vitamin $\mathrm{E}$ and vitamin B1 for four weeks. Acetylsalicylic acid (10 mg/ $\mathrm{kg}$ bwt, per os once a day) was given for three weeks.

\section{OUTCOME}

The horse was represented one month after the initial clinical signs and was clinically and neurologically normal. The horse subsequently returned to his previous level of jumping.

\section{DISCUSSION}

In this case report, an eight-year-old warmblood sport horse is presented with acute nonprogressive, asymmetrical neurological signs. The head turn and compulsive circling without ataxia were indicative for an asymmetrical forebrain lesion (Jose-Cunilleras and Piercy, 2007; Furr and Reed, 2015). Although animals suffering from intracranial disease can have an altered mental status, this was not observed in the present case (Furr and Reed, 2015). Compulsive circling may also be observed in vestibular disease and is usually accompanied by a head tilt and/or nystagmus (Johnson and Kellam, 2001; Furr and Reed, 2015), which was not found in the horse of the present case. The most common cause of vestibular disease is temporohyoid osteoarthropathy.

Other less frequently encountered causes include trauma, EPM, polyneuritis equi, otitis media-interna and neoplasia (Johnson and Kellam, 2001). Differential diagnosis of forebrain pathology includes trauma, inflammatory (infectious or noninfectious), metabolic or toxic disease (Divers, 2006; Hillock et al., 2006). In the present case, a traumatic event, inflammation or neoplastic processes were ruled out based on the results of the ancillary tests. CSF analysis didn't reveal any indication for an inflammatory or infectious process. EPM is a disease affecting the central nervous system due to the protozoa Sarcocystis neurona. The clinical signs may vary from an acute to insidious onset of neurological signs involving the brain, brainstem, spinal cord or a combination of these locations. Most commonly, signs are asymmetrical and include ataxia and/or muscle atrophy, but the clinical signs are variable and can simulate other equine neurological diseases (Furr et al., 2002). It is commonly described in North, Central and South America where the definitive host (opossum) is present (Furr and Howe, 2015), but some suspected cases in Europe have been reported too (Pitel et al., 2002). Although this horse had not travelled abroad and had not been in contact with travelling horses, EPM was tested because of the asymmetrical clinical signs; however, the results were negative. Antemortem diagnosis is usually presumptive and the definitive diagnosis is made postmortem by microscopic identification, immunohistochemistry, culture or polymerase chain reaction (Johnson et al., 2010). Different commercial tests exist (surface antigen 1 ELISA, Western blot and indirect fluorescent antibody) (Duarte et al., 2003; Johnson et al., 2010). Western blot was used in the present case but it has variable sensitivity and specificity on serum and CSF (Daft et al., 2002; Johnson et al., 2010). As both serum and CSF samples were negative and because the horse hadn't travelled abroad, EPM was highly unlikely.

Neuroborreliosis $(\mathrm{NB})$ is a syndrome attributed to Borrelia burgdorferi infection, a spirochete transmitted by Ixodes ticks. Clinical signs can be vague and variable. They include muscle atrophy or weight loss, cranial nerve deficits, ataxia, change in behavior and dysphagia (Divers et al., 2018). Antemortem diagnosis of NB is challenging due to variable clinical presentation and lack of a gold standard test (Johnstone et al., 2016). In the present case, serum antibodies were 
absent, which means that it is unlikely that this horse had ever been in contact with $B$. burgdorferi. Further examination of the CSF was not performed. However, it is important to report that negative serology can occur in acutely infected horses, immune-compromised horses or when the infection is localized to the eye or central nervous system (Johnstone et al., 2016; Divers et al., 2018). Nevertheless, looking at the evolution and the positive outcome of this case, NB was unlikely.

This horse didn't present any signs of progressive symmetrical paresis or ataxia, so spinal ataxia and EHV-1 were ruled out based on the clinical findings (Wilson, 1997; van Maanen, 2002). Borna disease and other equine neuropathogenic viruses, i.e. West Nile virus, Eastern equine encephalitis, Western equine encephalitis, etc. causing encephalitis or myeloencephalitis, are also possible differential diagnoses. Based on the asymmetrical clinical findings, no history of hyperthermia and on the absence of an altered mentation, these infectious diseases seemed unlikely and were not tested in this case. CSF analysis is often helpful in diagnosing encephalitis as there can be changes in protein and leucocytes concentration (Lecollinet et al., 2020). CSF analysis was performed in this case but was found to be normal.

On the CT-scan, no abnormalities were noted that could explain the symptoms. Different timing and contrast injection protocols (IV or intra-arterial; bilateral or unilateral) may influence the image interpretation (Nelson et al., 2017). While it is really sensitive to detect acute hemorrhage, early CT signs of ischemia can be subtle and difficult to detect (Hoggard et al., 2002; Garosi, 2010). With higher resolution and optimal contrast administration, CT images could probably have shown a filling defect (Nelson et al., 2017). Indeed, CT-perfusion or CT-angiography contrast protocols would have been more sensitive methods to detect a stroke (Arnold et al., 2020).

MRI is the most sensitive imaging modality for diagnosing ischemic stroke. Changes can be detected within 12 to 24 hours after the onset of clinical signs (Garosi and McConnell, 2005). In the present case, no ischemic changes were seen on MRI. Only a low field MRI and 4-mm slices were available, so subtle lesions could have been missed. High-field MRI is a superior technique for imaging of subtle lesions but was not available. Considering the inferior anatomical resolution of low-field MRI, diffusion-weighted imaging or apparent diffusion coefficient mapping would have increased the detection of ischemic infarcts (Arnold et al., 2020). Both MRI and CT were initially performed to exclude any obvious intracranial pathology and no vascular protocol was applied. Also, brain imaging in horses can be challenging. In a study reviewing equine head MRIs, no changes were noted in 70\% of horses presenting neurological symptoms (Manso-Diaz et al., 2015).

The flow difference between the venous sinuses might be an incidental finding. The flow difference could also be a flow artefact (time of flight artefact) or occur after a cerebral venous sinus thrombosis (CVST). In humans, CVST mostly presents as headaches, visual deficits and seizures but clinical symptoms are very variable (Yenigün et al., 2015). CVST has never been described in horses. Because in the present case, typical pathologies potentially giving right side forebrain signs could be excluded through ancillary testing, and because of the clinical evolution and positive outcome, a cerebrovascular event was plausible. However, definitive diagnosis of a cerebrovascular event (hemorrhagic or ischemic) should be made based on advanced medical imaging. CT-scan has the benefit of rapid image acquisition and is useful to detect hemorrhage. If available, high field MRI with a vascular protocol should be performed. T2W and FLAIR images are particularly useful in imaging an ischemic stroke, and diffusion-weighted imaging can improve the sensitivity and specificity of stroke diagnosis (Garosi, 2010; Arnold et al., 2020). Little data is available regarding cerebrovascular disease in horses. In all forms of stroke in humans and dogs, a clinical characteristic is the abruptness with which the neurological deficits develop in contrast to metabolic, inflammatory or neoplastic conditions that tend to have a more subtle onset and where the disease progression can be more gradual (Garosi and McConnell, 2005). Another clinical feature of stroke is that the neurological deficits stop progressing and then regress after a short period of time, except in fatal strokes in humans (Garosi and McConnell, 2015).

In dogs, the general goal of treatment is to provide supportive care, maintain adequate tissue oxygenation and manage possible complications (Garosi, 2010). In the present case, prednisolone was started at initial presentation before ancillary testing was performed and it was continued as the horse kept improving clinically. The use of glucocorticosteroids is controversial and there is no evidence of beneficial effects in the treatment of stroke in dogs or in humans (Sandercok and Soane 2001; Platt et al., 2005). Antibiotic treatment was also started at initial presentation and continued after discharge but in retrospect, treatment should probably have been terminated when the diagnosis was made. Vitamin B1 is thought to have a supporting role on the regeneration of the nervous system; however, evidence-based information for its efficacy is lacking. Vitamin E was administrated as an additional supportive treatment for its antioxidant properties (Finno and Valberg, 2012). Acetylsalicylic acid was started on the owner's initiative as it is used prophylactically in human patients who have exhibited a cardiovascular or cerebrovascular event (Hacke et al., 2003). To the authors' knowledge, in veterinary medicine, no controlled studies have assessed this treatment in case of cardiovascular or cerebrovascular pathology.

In a study inducing an ischemic stroke in dogs, 
clinical signs spontaneously regressed within four weeks without therapy (Kang et al., 2007). The prognosis in dogs with ischemic stroke has been described as fair to good depending on the presence or absence of an underlying condition (Garosi et al., 2005; Garosi and McConnell, 2005; Wessmann et al., 2009). In contrast, forebrain pathologies like brain tumors or abscesses, epilepsy, neuroborreliosis and metabolic encephalopathy, also described in equine medicine, may have a more reserved prognosis (Granstrom et al., 1992; Fenger et al., 1997; Ruas et al., 1997; Cornelis et al., 2001; Müller et al., 2011; Spoormakers et al., 2003; Audigie et al., 2004; Imai et al., 2011; Lacombe et al., 2011; Johnstone et al., 2016; Broux et al., 2019). In the horse of the present case however, the outcome was excellent.

\section{CONCLUSION}

In the horse of the present case, the clinical signs of an asymmetrical forebrain lesion were presumably caused by an ischemic vascular event. First, the clinical presentation corresponded to what is observed in strokes. Medical imaging didn't reveal any signs of trauma like parenchymal bleeding or skull fracture, and most common cerebral pathologies that give rise to asymmetrical forebrain symptoms could be ruled out. Finally, a reduced flow was found in the venous sinus, which can be an indication for a cerebrovascular event. Despite the marked neurological signs at the onset, full recovery was observed.

\section{REFERENCES}

Adams R. D., Victor M.(1997). Cerebrovascular diseases. In: Adams R. D. and Victor M. (editors). Principles of Neurology. Sixth edition, New York, McGraw-Hill Inc, p. 777-783.

Aleman M. (2018). Cerebrospinal fluid. In: Pusterla N. and Higgings J. (editors). Interpretation of Equine Laboratory Diagnostics. First edition, John Wiley \& Sons, Inc., p. 393-400.

Arnold A., Platt S., Gendron K., West F. (2020). Imaging ischemic and hemorrhagic disease of the brain in dogs. Frontiers in Veterinary Science 7, 1-18.

Audigé F., Tapprest J., George C., Didierlaurent D., Foucher N., Faurie F., Houssin M., Denoix J-M. (2004). Magnetic resonance imaging of a brain abscess in a 10-month-old filly. Veterinary Radiology \& Ultrasound 45, 210-215.

Broux B., van Bergen T., Schauvliege S., Vali Y., Lefère L., Gielen I. (2019). Successful surgical debridement of a cerebral Streptococcis equi equi abscess by parietal bone flap craniotomy in a 2-month-old Warmblood foal. Equine Veterinary Education 31, 58-62.

Bagley R. S., Gavin P. R., Moore M. P., Silver G. M., Harrington M. L., Connors R. L. (1999). Clinical signs associated with brain tumors in dogs: 97 cases (1992-1997). Journal of the American Veterinary Medical Association $15,818-819$.

Cornelisse C. J., Schott II H. C., Lowrie C. T., Diana S.
Rosenstein D. S. (2001). Successful treatment of intracranial abscesses in 2 horses. Journal of Veterinary Internal Medicine 15, 494-500.

Daft B. M., Barr B. C., Gardner I. A., Read D., Bell W., Peyser K. G., Ardans A., Kinde H., Morrow J. K. (2002). Sensitivity and specificity of western blot testing of cerebrospinal fluid and serum for diagnosis of equine protozoal myeloencephalitis in horses with and without neurologic abnormalities. Journal of the American Veterinary Medical Association 221, 1007-1013.

Divers T. J. (2006). Structural and functional diseases of the equine brain. Clinical Techniques in Equine Practice 5, 67-73.

Divers T. J., Gardner R. B., Madigan J. E., Witonsky S. G., Bertone J. J., Swinebroad E. L., Schutzer S. E., Johnson A. L. (2018). Borrelia burgdorferi infection and lyme disease in North American horses: a consensus statement. Journal of Veterinary Internal Medicine 32, 617-632.

Duarte P. C., Daft B. M., Conrad P. A., Packham A. E., Gardner I. A. (2003). Comparison of a serum indirect fluorescent antibody test with two Western blot tests for the diagnosis of equine protozoal myeloencephalitis. Journal of Veterinary Diagnostic Investigation 15, 8-13.

Erlen A., Potschka H., Volk H. A., Sauter-Louis C., O’Neill D. G. (2018). Seizure occurrence in dogs under primary veterinary care in the UK: prevalence and risk factors. Journal of Veterinary Internal Medicine 32, 1665-1676.

Fenger C. K., Granstrom D. E., Langemeier J. L., Stamper S. (1997). Epizootic of equine protozoal myeloencephalitis on a farm. Journal of the American Veterinary Medical Association 210, 923-927.

Finno C. J., Valberg S. J. (2012). A comparative review of vitamin $\mathrm{E}$ and associated equine disorders. Journal of Veterinary Internal Medicine 26, 1251-1266.

Furr M., Howe D. K. (2015). Equine protozoal myeloencephalitis. In: Furr M., Reed S. (editors). Equine Neurology. Second edition, John Wiley \& Sons, Inc., 285-305.

Furr M., MacKay R., Granstrom D., Schott H., Andrews F. (2002). Clinical diagnosis of equine protozoal myeloencephalitis (EPM). Journal of Veterinary Internal Medicine 16, 618-621.

Furr M., Reed S. (2015). Examination of the nervous system. In: Furr M. and Reed S. (editors). Equine Neurology. Second edition, John Wiley \& Sons, Inc., p. 67-78.

Garosi L. (2010). Cerebrovascular disease in dogs and cats. Veterinary Clinics Small Animal Practice 40, 65-79.

Garosi L.S., McConnell J. F. (2005). Ischaemic stroke in dogs and humans: a comparative review. Journal of Small Animal Practice 46, 521-529.

Gonçalves R., Carrera I., Garosi L., Smith P.M., McConnell J.F., Penderis J. (2011). Clinical and topographic magnetic resonance imaging characteristics of suspected thalamic infarcts in 16 dogs. The Veterinary Journal 188, 39-43.

Granstrom D. E., Alvarez Jr. O., Dubey J. P., Comer P. F., Williams N. M. (1992). Equine protozoal myelitis in panamanian horses and isolation of Sarcocystis neurona. Parasitology 78, 909-912.

Hacke W., Kaste M., Bogousslavsky J., Gugging M., Chamorro A., Lees K., Leys D., Kwiecinski H., Toni D., Olsen T., Langhorne P., Diener H., Hennerici M., Ferro J., Sivenius J., Wahlgren G., Bath P. (2003). European Stroke Initiative Recommendations for Stroke Management - Update 2003. Cerebrovascular Diseases 16, 311-337.

Hansen M., Christoffersen M., Thuesen L. R., Petersen 
M. R., Bojeses A. M.(2010). Seroprevalence of Borrelia burgdorferi sensu lato and Anaplasma phagocytophilum in Danish Horses. Acta Veterinaria Scandinavica 52, 1-6.

Hillock S. M., Dewey C. W., Stefanacci J. D. (2006). Vascular encephalopathies in dogs: risk factors, pathophysiology, and clinical signs. Compendium on Continuing Education for the Practising Veterinarian 28, 196-207.

Hoggard N., Wilkinson I. D., Paley M. N. I., Griffiths P. D. (2002). Imaging of haemorrhagic stroke. Clinical Radiology 57, 957-968.

Holland C. T., Charles J. A., Smith S. H., Cortaville P. E. (2000). Hemihyperaesthesia and hyperresponsiveness resembling central pain syndrome in a dog with a forebrain oligodendroglioma. Australian Veterinary Journal 78, 676-680.

Imai1 D. M., Barr B. C., Daft B., Bertone J. J., Feng S., Hodzic E., Johnston J. M., Olsen K. J., Barthold S. W. (2011). Lyme neuroborreliosis in 2 horses. Veterinary Pathology 48, 1151-1157.

Johnson A. L., Burton A. J., Sweeney R. W. (2010). Utility of 2 immunological tests for antemortem diagnosis of equine protozoal myeloencephalitis (Sarcocystis neurona Infection) in naturally occurring cases. Journal of Veterinary Internal Medicine 24, 1184-1189.

Johnson P. J., Kellam L. L. (2001) The vestibular system. Equine Veterinary Education 13, 141-150.

Johnstone L. K., Engiles J. B., Aceto H., Buechner-Maxwell V., Divers T., Gardner R., Levine R., Scherrer N, Tewari D., Tomlinson J., Johnson A. L. (2016). Retrospective evaluation of horses diagnosed with neuroborreliosis on postmortem examination: 16 cases (2004-2015). Journal of Veterinary Internal Medicine 30, 1305-1312.

Jose-Cunilleras E., Piercy R. (2007). Advanced diagnostic imaging options in horses with neurological disease that localises to the head. Equine Veterinary Education 19, 179-181.

Kalimo H., Kaste M., Haltia M.(2002). Vascular diseases. In: Graham D. I. and Lantos P. L. (editors). Greenfield's Neuropathology. Seventh edition, London: Arnold, p. 233-280.

Kang B-T., Lee J-H., Jung D-I., Park C., Gu S-H., Jeon H-W., Jang D-P., Lim C-Y., Quan F-S., Kim Y-B., Cho Z-H., Woo E-J., Park H-M. (2007). Canine model of ischemic stroke with permanent middle cerebral artery occlusion: clinical and histopathological findings. Journal of Veterinary Sciences 8, 369-376.

Lacombe V. A., Mayes M., Mosseri S., Reed S. M., Fenner W. R., Ou H. T. (2012). Epilepsy in horses: aetiological classification and predictive factors. Equine Veterinary Journal 44, 646-651.

Lecollinet S., Pronost S., Coulpier M., Beck C., Gonzalez G., Leblond A., Tritz P. (2020). Viral equine encephalitis, a growing threat to the horse population in Europe? $\mathrm{Vi}$ ruses 12, 23.

Manson-Diaz G., Dyson S., Dennis R., Garcia-Lopez J., Biggi M., Garcia-Real M., San Roman F., Taeymans O. (2015). Magnetic resonance imaging characteristics of equine head disorders: 84 cases (2000-2013). Veterinary Radiology and Ultrasound 56, 176-187.
Müller J.-M., V., Schulze M., Herder V., Lautenschläger I., Baumgärtner W., Feige K. (2011). Ataxia and weakness as uncommon primary manifestations of hepatic encephalopathy in a 15-year-old trotter gelding. Equine Veterinary Education 23, 5-10.

Mygland A., Ljostad U., Fingerle V., Rupprecht T., Schmutzhard E., Steiner I. (2010). EFNS guidelines on the diagnosis and management of European lyme neuroborreliosis. European Journal of Neurology 17, 8-16.

Nelson B., Goodrich L., Barrett M., Grinstaaf M., Kawcak C. (2017). Use of contrast media in computed tomography and magnetic resonance imaging in horses: Techniques, adverse events and opportunities. Equine Veterinary Journal 49, 410-424.

Pitel P-H., Pronost S., Gargala G., Anrioud D., Toquet M-P., Foucher N., Collobert-Laugier C., Fortier G., Ballet J-J. (2002). Detection of Sarcocystis neurona antibodies in French horses with neurological signs. International Journal for Parasitology 32, 481-485.

Platt S. R., Abramson C. J., Garosi L. S. (2005). Administering corticosteroids in neurologic diseases. Neurology Compendium 17, 210-221.

Ruas J. L., Schild A. L., Fernande C. G., Montiel Ferreira J. L., Müller G. (1997). Cerebral Equine hydatidosis in Southern Brazil. Ciência Rural Santa Maria 27, 341-344.

Sacco R.L. (1994) Classification of stroke. In: Fisher M. (editor). Clinical Atlas of Cerebrovascular Disorders. London, Wolfe, p. 2-25.

Sandercock P. A. G., Soane T. (2011). Corticosteroids for acute ischaemic stroke. Cochrane Database of Systematic Reviews 9, 1-18.

Spoormakers T. J. P., Ensink J. M., Goehring L. S., Koeman J. P., Ter Braake F., van der Vlugt-Meijer R. H., van den Belt A. J. M. (2003). Brain abscesses as a metastatic manifestation of strangles: symptomatology and the use of magnetic resonance imaging as a diagnostic aid. Equine Veterinary Journal 25, 146-151.

Thomas W. B. (1996). Cerebrovascular disease. Veterinary Clinic of North America: Small Animal Practice 26, 925-943.

van Maanen C. (2002). Equine herpesvirus 1 and 4 infections: An update. Veterinary Quarterly 24, 57-78.

Wessmann A., Chandler K., Garosi L. (2009). Ischaemic and haemorrhagic stroke in the dog. Veterinary Journal 180, 290-303.

Wilson W. D. (1997). Equine herpesvirus 1 myeloencephalopathy. Veterinary Clinics of North America: Equine Practice 13, 53-72.

Yenigün M., Jünemann M., Gerriets T., Stolz E. (2015). Sinus thrombosis - do animal models really cover the clinical syndrome? Annals of Translational Medicine 3, 138-145.

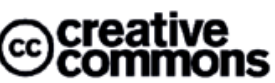

C) 2021 by the authors. Licensee Vlaams Diergeneeskundig Tijdschrift, Ghent University, Belgium. This article is an open access article distributed under the terms and conditions of the Creative Commons Attribution (CC BY) license (http://creativecommons.org/licenses/by/4.0/). 